\title{
Cultural Theory from Dichotomy to Interface: Travelling Theory and Saidian Dialectics
}

\author{
Mohamed Hamoud Kassim Al-Mahfedi \\ University of Al-Baydha, Republic of Yemen
}

Doi: 10.19044/llc.v6no4a1

URL:http://dx.doi.org/10.19044/1lc.v6no4a1

\begin{abstract}
This paper attempts to answer this question: with the cartelization of homogenously global cultural market that suffuses the space of human ideas, is it still possible to formulate a cultural theory or conceptual theoretical framework which sounds neither rhetorically hollow nor disablingly pessimistic? If so, is it possible to take Edward Said's concept of travelling theory as an apposite starting point? Adopting a cultural relativist critical approach, the paper probes into Said's polemics. Said's vision of Andalusia as both an idea and location, particularly vis-à-vis recent cultural crises that have stricken the region, serves a starting point of injection and departure. The paper concluded that it is to this end of cultural design that Said's dialectics posits itself noteworthy.
\end{abstract}

Keywords: Orientalism, Cultural Theory, Cultural Relativism, Cosmopolitanism, Postmodernism, Critical discourse.

\section{Introduction}

With the cartelization and globalization of cultural markets and information orders that plague the space, is it still possible to formulate a cultural theory or conceptual theoretical framework which sounds neither rhetorically hollow nor disablingly pessimistic? If it is, an apposite starting point might be Edward Said's image of Travelling Theory". His argument is that theories have no fixed politico- cultural meaning, but take on different implications depending on where, when and how they are deployed. Said welcomes the mobility of travelling theories because they can unblock intellectual and cultural formations. But, he cautions that they can also be a trap; they can become dogmatic. So, how can one avoid dogmatism and stay responsive? Human ideas are translated and transfer in a variety of registers. Hence, cultural practitioners should think of new alternatives, of possible negotiation between theoretical discourses and cultural market-place. It is to this end of cultural design as a value system of human contact that Said's 
dialectics posits itself, rather than to wrapped cultures of shibboleth gesture. Said's "Andalusia's Journey," a brief essay published in Travel and Leisure in 2002 , is a referential point of reflection and exploration in this paper. Said's vision of Andalusia as both an idea and as a location where the interaction between cultures demands new reflections, particularly vis-à-vis recent migratory flows that have stricken the region serves a starting point of injection. Consequently, this paper probes into Said's polemics and how it opens a new vista of cultural criticism based on intellectual openness and civilizational communication rather than on binary dichotomous thinking.

\section{Said's Travelling Theory}

Said's identity was constructed in extremely tense politico-cultural atmosphere. His experience of Palestine as history and cause shaped his cultural theory and criticism. He shared the stings of dispossession and the pleasure of exile. This endows him with a critically detached position, "to speak from the position of both 'insider' and 'outsider'. As stated by AlMahfedi (2013, p.170), Said has undergone the experience of colonialism, imperialism, neocolonialism and globalism".

From such a perspective, Said's predicament is moral and humanistic rather than material. These early conditions endowed him with a humanistic spectrum that helped him relate his critical concepts to the circumstantial reality and gave rise to his oppositional criticism "as life-enhancing and constitutively opposed to every form of tyranny, domination, and abuse; its social goals are noncoercive knowledge produced in the interests of human freedom" (Said, 1983, p.29). His exile conceptualizes his humanistic dilemma whereby homelessness becomes a state of mind. The significance of exile is both poignant and stirring as it undergoes his contrapuntal experiences of both Self and Other -- being a Palestinian living in exile.

Nomadism is a salient feature of his thought, and criticism for him is a "nomadic, decentered, and contrapuntal" event (Said, 2001, p.186).Therefore, he was neither subject to the power of his national filiations nor to his cultural restraints, but a "sense of being between cultures . . . in and out of things" (Parry, 1992, p.19).

Said's critical endeavor of undoing the hierarchical structure of thought and the invention of historical truth demonstrates a constant cultural relativist trend. Polyphony and counterpoint are two significant strategies of his cultural theory. His work offers ample occasion for viewing polyphony as a representation of a humanist community, as an emancipatory model, and as a social model that entails the welcoming of difference without othering, dissidence without oppression, acceptance without domination, and diversity in human equality. As he puts it in Culture and Resistance, the ultimate goal is "to break out of our self-constructed mind-forged manacles and look at the 
rest of the world and deal with it as equals" (2003, p.20). He rejects the mythicizing of history as a tool to create facts and celebrated honoring facts and demystifying myths. His work operates both processes of demythologization and demystification.

Said was an activist with deeply humanist worldview and critical mind who emphasized secularism and constantly warned against bringing religion into the realm of knowledge and politics. He underestimated the moral and intellectual appeal of religious traditions and a religious approach to knowledge. Regarding his treatment of the question of Palestine, Said's uncompromisingly secular and anti-sectarian views at times made his visions for the future seem incompatible with the region's realities. His rejection of essentialism reinforces his rejection of absolute truths, or the claim to it.

In line with this, to suggest that Orientalsim was written as an outcry and an assertion of his Palestinian nationalism would be anathema to his view of the secular role of the public intellectual which is to open spaces across borders. The shift from the nationalist attitude to humanist consciousness and sacrificing of the affiliation of one's persecution to that of others found their natural culmination in Said's understanding of the question of Palestine. The greatest irony about his influence is the fact that the Palestinian experience of suffering, dispossession, denial, death, and elimination was the very experience which had shaped his worldly-wise consciousness, his intellectual generosity and ethical wakefulness.

This culturally relativist trajectory was integrated into his cosmopolitan panhuman undertakings. This cultural trend was manifested in his rejection of the chauvinistic and racist criteria that "define a person not by his/her ideas and values, but by his racial origins, religion, or culture" (Said, 2003, p.264). The facility to think in terms of alternative ideas, alternative political strategies, and alternative readings for the sake of others was what determined Said's immense contribution to the Palestinian cause. He projects Jerusalem as an exemplary idea "of illuminating the difference between an exclusivist, narrowly ideological perception of history and society, and . . . a vision that is catholic, inclusive, and liberating" (Said, 1995, pp.11-12).

The argument of this paper is built on the premise that the world has been so far governed by binary and dichotomous thinking based on power/knowledge constellation, and that its view of the "Other" has been primarily hierarchical and ideologically political. It is also premised that the concept of Orientalism as an ideology of othering was the product of European historicism that placed Europe at the center of the universe and the producer of world history.

Hence, Said's critical and theoretical approach to this issue is significant. He has been lauded as one of the pioneer thinkers in terms of political critique of otherness. His polemics have promoted a flexible 
dialectical entwinement of the broad allegorical uses of the concept of the Other with a precise historical and geographical orientation toward discourses and conditions that produce others in real social situations. Otherness, for Said, has never been a pure philosophical concept; it was never disembodied. In fact, it is precisely in this dialectical understanding of otherness that the epistemological impact of Orientalism resides, beyond the scope of its object of inquiry. Contrary to what certain critics think, Said has been consistent in this respect -- from Orientalism to the late essay Freud and the Non-European. He has always been a non-identitarian thinker who believed in the universality of the intellectual as a voice of all humanity not of his own native or natural identity. Therefore, he sees the fetishism of the concept of otherness essentially nothing less than the most basic nativism and blatantly uncritical self-orientalization.

Travelling Theory represents the keynote idea that suffuses and explicates Said's entire intellectual oeuvre. By stating that theory is immersed in its worldliness, Said reveals its true nature as a down-to-earth theoretician. In his 1982 essay on "Traveling Theory", Said argues that the transfer of ideas in the humanities and the social sciences is influenced by both "conditions of acceptance" and "resistances". The journey of theories, he explains, is never unimpeded. However, these "conditions," he insists, might sustain an element of cultural exclusion or ethnic segregation unless subjected to the touch-stone of critical consciousness. "Critical consciousness" he argues, "is awareness of the differences between situations, awareness too of the fact that no system or theory exhausts the situation out of which it emerges or to which it is transported". (Said,1983, p. 242)

Said's remedies for the dichotomous, Manichean worldview can be traced to his theories of worldliness, travelling theory, journeying in and contrapuntality. By worldliness, Said refers to the situatedness of events or actual realities away from fixed stereotypical predetermined conceptualizations. Travelling theory is a term used by Said to refer to the transfer of ideas across cultures, and how they are received as a cultural relativist phenomenon. Therefore, theories/ideas pass by or journey in threeway process: acceptance, modulation, or rejection. Said crowns his cultural theory by introducing the concept of contrapuntality, a term he borrows from musical art, to refer to the reading of cultural event from two perspectives simultaneously so as to come up with a clear and fair judgment. Thus, he insists that we should read the text from the views of the insider and the outsider, the colonized and the colonizer, the local and the global since geographies are intermingled and histories are intertwined. Historical experience, he argues, is interlocuted creation of the all participants.

These theories and concepts sum up his critical thought as a strategy of value system. He sees more of "interface than dichotomy in the world 
cultures". Accordingly, "worldliness necessitates a belonging to the world of humanity as a whole, and a breaking with the parochial, nativist and other provincial filiations". This realization of the dynamism of human civilization and the dialogic nature of human culture remind us that "theories, thoughts and cultural elements travel with us, by us and through us as civilizational and cultural centers revolve and move." (Al-Mahfedi, 2013, pp.173-74)

\section{Saidian Dialectics}

The phenomenon of traveling elucidates Said's own theory of text and author, as well, especially to his famous notion of Orientalism. What is more appealing in Said's position is the celebratory concepts of secular criticism and humanism as "a means of questioning, upsetting, and reformulating so much of what is presented to us as commodified, packaged, uncontroversial and uncritically codified certainties" (Said, 2004, p.27). To serve this end of critical endeavor, he castigates intellectual professionalism that ingrained ethnocentric and monolithic cultural operations. Professionalization and intellectual consent preserve hegemony and totalitarian authority by creating "cultural dogma", and "sublimat[ing] ethnocentrism and nationalism". (Said, 1983, p. 25)

Literature is not "a passive structure"; it is "an act" located in the world" and one cannot "divorce the text, which is a cultural production, a cultural act, from [its worldliness], the relations of power within which it is produced (Ashcroft \& Ahluwalia, 2001, p.18). Hence, the author/critic's intellectual independence is necessary for literary criticism since "literature is based on the undeniable existence ... of a complex network of interests, from racial and political to disciplinary or 'civilizing,' which conditions the way in which authors represent their world" (Alfonso, 2001, pp.51-52). A literary text is not only part of that secular, long-established institution called literature but also a new possible horizon of intelligibility within social, political and ethical positions which always have a historical dimension. Said puts this idea, as it is developed in the Western novel, in the following terms: "Novels . . . are aesthetic objects that fill gaps in an incomplete world: they satisfy a human urge to add to reality by portraying (fictional) characters in which one can believe". (1975, p. 82)

$\mathrm{He}$ also decries institutional agencies as a totalitarian instrument of fixation, "contemporary criticism is an institution for publicly affirming the values of our, that is, European, dominant elite culture, and for privately setting loose the unrestrained interpretation of a universe defined in advance as the endless misreading of a misinterpretation"(Said,1983, p.25). To redeem all these dogmatic jargons, he proposes the concept of "critical consciousness" as an intellectual exercise that interrogates received ideas and theories by offering "a valid reformulation" of worldly nature of literary studies and 
"freeing criticism from the usually egotistic, normative anti coercive politics of textuality ... so characteristic of our age." (Alfonso, 2001, p.50). To put it differently, cultural symbols and ideas are always situational and never be universal.

Said's cultural theory encompasses geo-cultural transformations and the incumbent cultural formations. In its core, his idea accentuates the interactive nature of cultures than compartmentalizing them into fixed categories. The extraordinary impact of his critical and cultural thought is its obliteration of castigated boundaries constructed by politico-cultural norms. Said, therefore, must be studied not for himself as a cultural individual voice, but for his contribution to the public thought as a collective picture of a redeeming cultural force today. His theory challenges readers to question the stereotypes that relegate people who are different from us, and rethinks the role of others not as others but as real interlocutors, participants and producers of cultural event. It also begs the question, whether human rights are universal or another example of western imposition and cultural imperialism.

The problem with the public intellectuals today is to lack a panoptic vision that enables them to read the world contrapuntally. They are bound by an either/or faulty conceptions, and consequently fail to address human issues fairly. Said's cultural dialogism offers a critical foundation for undoing the dominant concepts and putting in their place an alternative critical negotiation and reconciliation as a tool of survival, where dialogue replaces polarization. His incessant stand is that "No one today is purely one thing" and that "Labels like Indian, or woman, or Muslim, or American are not more than startingpoints" since "human beings make their own history ... their cultures and ethnic identities". Histories are overlapped and geographies are intermingled, and human culture has gone through "persisting continuities of long traditions, sustained habitations, national languages, and cultural geographies". To rule over fear and prejudice, he opines, is to "think contrapuntally, about others than only about 'us'" (Said, 1994, p.336)

Since cultural norms are identity-operating signals, Said debunks dichotomous construction and focalization of identity as a monolith fixed object. He argues that a person's identity is multifaceted and is always evolving. He contests Samuel Huntington's thesis as set out in The Clash of Civilizations and the Remaking of World Order (1996) that the "the principal conflicts of global politics will occur between nations and groups of different civilizations. The clash of civilizations will dominate global politics" (p.32). According to Said "Rather than the manufactured clash of civilizations, we need to concentrate on the slow working together of cultures that overlap, borrow from each other, and live together in far more interesting ways than any abridged or inauthentic mode of understanding can allow." (1978, p. 22) In fact, Huntington's book is a "manual in the art of maintaining a wartime 
status" that belongs to the discourse of Othering, "a construction fabricated to whip up feelings of hostility and antipathy against a part of the world that happens to be of strategic importance." Said, YouTube, np)

Said's theory juxtaposes humanist postulates with cultural relativist positions. a Hence, Said's thought need to be located neither in the realm of universalism, nor in the domain of ethnographic particularism; but within the contours of space where dialogic confabulations across human race is possible. This space is the space of co-articulation that subverts dichotomy, opposition and even symmetrical structures across cultures. Polyphony and counterpart are the two significant strategies of Sadian cultural theory. Such an intellectual sphere acquires a crucial role by using knowledge to open spaces across borders.

Saidian epistemological category is based on cultural reciprocation and secular tolerance. The idea of dichotomization is never part of his discourse. In a similar vein, his understanding of the "other" is not as "other" but part of the embodiment of the self. This is made possible by contrapuntal reasoning that restores concealed histories and abdicates power for better justice and equality for all human-beings. The east-west is never seen by Said as a polarity but a body of co-related cultures.

A text for Said is an embodiment of value-system of a particular culture. He is a down-to-earth theorist undertakes responsibility towards humanity whereby humanism for him is an experience of critical worldism, that is, our realities as they are in the world not as conceived or constructed abstract ideas. From this perspective, the greatest irony about Said's influence is that the Palestinian experience of dispossession, suffering and death becomes the very experience that shapes his universalist consciousness, his intellectual generosity, and his ethical wakefulness. Thus, Said's dialectical discourse "offers not only a renewed perspective on the problem of sociopolitical representation in literature, but also a constructive conception of literary theory as an exercise both in pluralism and in ethical engagement" that "supersedes any relativist profession "whether in the form of self-contained textualist formalism . . . or impressionistic celebrations of postmodern decenteredness" (Alfonso, 2001, p.59)

To eliminate cultural bias and prejudice, one has to undergo the privileged form of critical consciousness that prioritizes methods on the category of thought itself. For the sake of this, Said has built and developed the concepts of worldliness, travelling theory, contrapuntality, voyage in, and democratic humanism as strategic foundations of his critical method and approach. He advocates a radical embrace of all "that is worldly, circumstantial, or socially contaminated" in the interests of reconstituting the relation between "texts and the existential actualities of human life, politics, societies and events" (Said, 1983, p.5). Far from signifying the apotheosis of 
humanity, the notion of "culture" appeared to him as a system of evaluations or coercions that discriminates, prescribes, and proscribes. For this reason, he rejects the Arnoldian conception of culture and replaces it with a Vician idea of humanity bearing. He also dissolves the familiar distinction between culture and society or civilization in favor of an expanded sense of culture, carving a space for individual consciousness "at a sensitive nodal point" in which belonging does not connote conformity and functions as critical distance, but inhabits the site of a dialectical interplay between filiation and affiliation (Said, 1983, p.15). He crosses "discursive and institutional boundaries" and chooses "to write from our own displaced positions with precision and clarity" (Deer et al, 2006, p.1)

By deploying a conceptual view of culture that is affirmatively cosmopolitan, he has driven home to public the importance of reconciling one's identity and the actualities of one's own culture, society, and history to the reality of other identities, cultures, peoples. Likewise, by resolving the tension between historicizing the self and reificating and objectivizing the Other, by knowing ourselves in history as they are in the worldly world, by seeing ourselves as objects, he has suggested that we would be able to overcome the hierarchical and dichotomous effects of culture. This critical stand constitutes the main foundation of his concept of worldism. Therefore, he considers the classification of the world into Occident and Orient, the West and Islam, the North and the South etc., as a misleading trap, suitable only for "the mobilization of collective passions than for lucid understanding" (Said, 2004, p. 16). His critique of Orientalism and cultural hegemony, therefore, is not a void act of criticism or a mere expose of the mind. On the contrary, at the heart of his work is the question of alterity. Within the project carried out in Orientalism, he has specifically raised the question of alterity by highlighting the way in which the West has represented the East, its Other, according to an us and them dichotomy.

However, if Said criticizes Orientalism as a reflection of Western ethnocentrism, he castigates nativism as a reversed form of the same concept. Falsifying a dichotomy between East and West and essentializing the character and psyche of the Others constitutes a "human failing" on the part of these two extremes of centrism. He reminds us that "any attempt to force cultures and peoples into separate and distinct breeds or essences exposes not only the misrepresentations and falsifications that ensue, but also the way in which understanding is complicit with the power to produce such things as the 'Orient' or the 'West'", or essentialized identities (Said, 1978, p.349).

The importance of Said emerges from his in-between link that has undone and done certain points of departure in the colonial and postcolonial discourses. While disestablishing and destabilizing the Orientalist/colonialist and imperialist assumptions of Western superiority and supremacy, he has 
called for Arab and Muslim scholars to study the other cultures with fair critical insights and secular visions. He has encouraged the use of voyage in as a valuably critical tool for understanding the other.

Said has dealt with the concept of dichotomy between the Occident and Orient from the vantage point of both an insider and outsider. Being an Arab Palestinian living in the West, he has been endowed with the potential of an intellectual who can read the human actions from a detached position. His approach to the concept is that of a postmodern cultural relativist who breaks away with the Orientalist essentialism and sheer Occidentalism. His method has disturbed the positions and relationships of postcolonial Subject/Object, and the way we look to the other. He diffuses the gaze between the object, the observed, and the subject, the observer, so that there would be no eternal studying subject and no eternal object of study. The relation between the Self and the Other is an equal relation, not a high-low relation, an even and sane inter-subjective relation instead of a superiority-inferiority complex. This constructive polemics is the Saidian substitute for the sheer Occidentalism that transforms the subject/object positions. He proclaims, "To leave the historical world for the metaphysics of essence ... is to abandon history for the essentializations that have the power to run human beings against each other" (Said, 1994, p. 229).

In the light of this view, the concept of "cultural purity" has been discarded as a form of essentialist discourse since essentialization breeds Othering and Othering produces hegemonic and totalitarian systems. Hence, opposing Us, the Self, and Them, the Other, is to choose a criterion that allows humanity to be divided inhumanly. To state it naïvely, difference belongs to the realm of fact and otherness belongs to the realm of discourse. He asserts, "There is, after all, a profound difference between the will to understand for purposes of co-existence and enlargement of horizons, and the will to dominate for the purposes of control" (1978, p. 14).

Invoking the present-day cultural scenarios, a more panhumanistic position that goes beyond humanist sectarianism becomes a human need that upholds human agency, open critical consciousness and the possibility of noncoercive, non-dominating kinds of knowledge. Panhumanism is an allembracing notion used by Said as an answer to the dichotomous Orientalist/colonialist divide of human race into human binaries. Said notions of intertwined histories and overlapping territories demonstrate that human historical experience is a mutual act of involvement. It is impossible to wipe out or cover up other's involvement. Humanity with its Orientals and Occidentals cannot escape the doom of cohabitation based on worldly relations as a process of cultural dialogue and positive interaction. Essentialist discourses and theories are exclusionary that always ensconce polarizations. Said's dialectics have ethically rejected the idea that there is such thing as "a 
pure race, a pure nation, or a pure collectivity" since cultural purity and essentialism are considered "human agglomerations . . . tantamount to organized discrimination or persecution". (Said, 1995, p. 81)

Summoning on his vision of Andalusia, Said places Palestine both as locale and as idea at the center of his critical project. This inclusively cosmopolitan vision of Palestine is that historically Palestine was - and still is - an immensely significant territory: an over-determined palimpsest, a place holy to three world religions, a site saturated with the mysterious entanglement, and a closed universal center whose transcendent meaning is antithetical to earthbound reality. Said frequently refers to the "historical example of Andalusian society lest we forget that different peoples can share a common history and, together, coexist to produce institutions of civil justice and artworks of extraordinary value and impact" (Bove, 2000, p. 2).

Significantly, Said's invocation of the Andalusian exemplary experience is significantly appealing here. Cultural dispossession, erasure, and denial on one hand, and acculturalization process, cultural nuisance and hegemony, on the other, pose a threat to human co-existence and cultural contact. Acculturalization is a process, though entails a cultural contact and exchange, it becomes a latent imperially cultural tool of imposition that markets cultural domination through consent.

The question of Palestine, among many other questions such as current refugee and migratory cultural crises, stands witness to the failings of all contemporary critical thoughts and theories and has become an ideational stigma of current globalized cultural theory that allegedly calls for cultural tolerance and co-existence. Amid these cartelized milieus, Said's polemics have emerged as a possible worldist relativist substitute for current universalist global cultural system, serving as a possible platform for future cultural diversity, tolerance and coexistence.

In this context, the image of Andalusia as a picturesque site to be toured, and as a location of interaction between cultures, demands new reflections, particularly vis-à-vis recent migratory flows that have stricken the region. Said's vision is highly conditioned by the multicultural past of the region, where Muslims, Christians and Jews lived together for centuries. "Thus, traveling to and in Andalusia also means negotiating the different meanings that the Andalusian cultural heritage attains in diverse contexts". (Linhard, 2011, p. 172)

The current cultural scenarios are backed by compelling urge for pluralistic vision of civilizational complexes, cultural diversity and connectivity at the same time. The inherited notions of divide that governs the global culture need to be reformulated with anew reflection of "the alternative mappings of the world." A close reading of Said's critical project would reveal his stringent zeal to bridge the cultural gap that has been created across 
accumulated process of backing ideologies and political motivations. "All essentializing strategies and concepts are discarded by Said as spuriously imposed identities on heterogeneous phenomena." (Al-Mahfedi, 2013, p.70)

"In order to invalidate the authority of a given culture or civilization as a predetermined force," Al-Mahfedi argues, "Said introduces the metaphor of the 'voyage' to describe the transfer of theories across cultures and civilizations." The main nexus of Said's travelling theory is to "connect the idea of volatility of civilization to ideas of 'interrelated cultures', 'intertwined histories' and 'overlapping territories'" (2013, p. 171). Cultures are fundamentally hybrid. Hence, any essentialist discourse is castigated by Said as it crisscrosses with the conceptual hybridity nature of culture. Consequently, he deflates the Orientalist discourse because it subjugates humanistic values and knowledge of the Other to the idea of specialization and professionalization. His main concern is: "Can one divide human reality . . . into clearly different cultures, histories, traditions, societies, even races, and survive the consequences humanly?" (Said, 1978, p. 45)

To develop it further, Said distinguishes between the Orientalist epistemological discourse of Othering as an ideologically constructive tool and mechanism that nourishes divide and hegemony, and difference as a natural distinguishable feature among peoples, cultures and individuals. On the same vein, he insists on the affiliative rather than filiative structure of subject position. The individual filiative bonds are seen by Said as a narrow essentialist stricture. Hence, Criticism for Said is "a method or system acquired affiliatively" (Said, 1983, p. 25). Said's critical pursuit "is precisely to demolish the conceptual constructions" of the inherent dominative mode of the binary opposition "that divide the world into confrontational cultures or hierarchical civilizations" (Ghazoul, 2004, pp.123-124) Said's critical strategy "depends upon and reinvents the critical and creative possibilities of literary history; . . . as an agency in the reorganization of cross-cultural relations in the current world". (Bove, 1993, p. 267) Culture for him is a domain of socializing human thinking and perception of himself and of others, as "a set of values and practices shared by human, but when it is stripped off of its humanistic values and concentrates only on the centrality of its own, it becomes an instrumental function that nurtures the hierarchical division". (Al-Mahfedi, 2013, p. 175)

This humanistically cosmopolitan heterogeneous view of culture exposes the failure of the Western view of culture and its exercise as "a homogenous universal frame" and subverts "its claim of inevitable superiority". Said's advocacy of a cultural relativist position "contests a culture's singularity and purity", that endows itself with "the sole right of judging, issuing views, constituting and communicating knowledge to other cultures, excluding the overlapped, intertwined and discrepant historical 
experiences shared by all world cultures." Said's argument, according AlMahfedi, is that "when a culture is based on an absolute element of nationalization, it becomes combative and aggressively repulsive to other cultures, and consequently, contributes to asserting man-made geographical boundaries, and enhances xenophia." (p.175) Mankind results from cultural hybridity and reciprocal communication. Being as such, a given culture is a result of, and, is in no way a state of constant reciprocity among all world cultures. In Representations of the Intellectual, Said reconfirms, cultures are too intermingled, their contents and histories too interdependent and hybrid, for surgical separation into large and mostly ideological oppositions like Orient and Occident (1994, 11-12). This cultural relativist stand of Said is applauded by Paul Bove as a celebratory contribution "because it comes from coalescence and not from difference alone" (Said, 2000, p. 8).

Consequently, his polemics are "prioritizing identity over difference or universality over locality do or can be deployed to justify the ongoing power relations between East and West or South and North" (Xie, 2009, p.77). For this end, he has insightfully espoused "a new geographical consciousness of a decentered or multiply-centered world", for "deal[ing] with disjunctive formations and experiences" (Said, 2001b, pp.471, 458). As he reprimands colonial culture because of its "clear-cut and absolute hierarchical distinction . . . between ruler and ruled," he also disapproves nativism because it "reinforces the distinction even while revaluating the weaker or subservient partner" (Said,1994, p. 228). He warns that "to accept nativism is to accept the consequences of imperialism, the racial, the religious, and political divisions imposed by imperialism . . . [and the] unthinking acceptance of stereotypes, myths, animosities, and traditions encouraged by imperialism" (Said,1994, pp. 228-29). As a result, the idea of "true liberation", as distinct from mere national independence, can only be won in a war of cleansing violence through "a transformation of social consciousness." He concedes that the "shift from the terrain of nationalist independence to the theoretical domain of liberation," requires "a fertile culture of resistance whose core is energetic insurgency, a "technique of trouble" " and sometimes armed insurrection (1994, pp 281, 230, 268, 267).

Said's essay "Andalusia's Journey" reinforce the idea of a lost paradise where watery gardens and shady patios served as a backdrop for the harmonious co-existence. The idealization of this co-existence, as well as the most famous myths of Andalusian culture accentuates Said's humanistic worldism. Said writes: "Andalusia was a particularly lively instance of the dialogue, much more than the clash of cultures" (2002, p.1) According to Tabea Linhard, "While the text initially displays a nostalgic vision of Andalusia, turning the region into an anachronistic model that would ideally aid in solving contemporary conflicts in the Mediterranean world, Said's 
writing ultimately reverses such a one-dimensional understanding of the region and its history" (2011, p.170). This conception of travelling is reiterated and echoed in several texts of Said, forming a consolidated vision of interactive role of culture, of coexistence, of interrelatedness and of overlapping. In Humanism and Democratic Criticism, he reiterates: "only in that precarious exilic realm can one first truly grasp the difficulty of what cannot be grasped and then go forth to try anyway." (2004, p. 144)

His humanism, then, is ultimately a product of his multifaceted nature as a literary critic, cultural theorist and political activist, and of his being an intellectual in exile. It is an emancipatory project to redeem human culture from the obtuse Manichean thinking, and subject human knowledge and experience to critical investigation of human cohabitation. For this reason, he censures the adoration of certain cultural pattern as an Arnoldian touchstone and destabilizes the canonical tradition of "the great works" that sublimate and subordinate others to secondary station. Therefore, "what is proceeded," he professes, "is an extended mediation on the usable scope of humanism as an ongoing practice and not as a profession,... what concerns me is humanism as a usable praxis". Accordingly, he rules out what can be called imposed humanism or "humanitarian intervention," for "many of its results struck people as inhumane" (Said, 2004, p. 6, 7). He considers these interventions as pure politics and double-edged ideology that single out one nation and closes eyes on another. For him injustice is injustice whether in Iraq, Rwanda, America, Palestine, etc.

\section{Conclusion}

Having recognized that there are different types of culture, intertwined histories of human experience, and overlapping territories of human geographies, this paper rests upon the recognition of equal interlocution that places the human above the political. In addition, to further convey the message of Said and for the sake of a serious dialogue and to keep it worthwhile and mutually respectable, it is to be highlighted that ideas, positions, and values can be much more effectively communicated through a naturally pluralistic reality, primarily in the form of peer-to-peer, face-to-face discussions, on the basis that the "Occident" and the "Orient" are willing and equal interlocutors.

It can be concluded that Occident-Orient dichotomy has been constructed and perpetuated over time by ideologically oriented goals and supported by a plenty of theoretical perceptions and assumptions. The concept of dichotomy is a created myth based on a Western view of the unity of world universal culture of the Center to dominate the periphery in the name of acculturation. There is no One Culture with capital C. There are only multiple cultures, in small c's. Each culture has its own autonomous life, an expression 
of a people and its history. Cultural interaction throughout history does not mean acculturation, the absorption of small cultures in the periphery by the big Culture of the center, assimilation, imitation, or modeling. It means an equal exchange, a give and take, a two-way movement on the levels of language, concepts, horizons, methods, and values.

Although he was not a cultural relativist in the radical sense, Said's cultural relativism has been incorporated into his polyphonic postmodern and cosmopolitan approach. Cultures for him are hybrid, human histories are intertwined and territories are overlapping. The enculturation process has been seen by Said as a normative factor that should not reveal a parochial or chauvinistic view of the other. His critical and cultural theory entailed that all societies demonstrate cultural diversity and dynamism and, therefore, no culture or society is superior or inferior to the other. Interactions between cultures prove that clear-cut dichotomies between cultures and peoples are false and all the significant and injustices and inequalities are the result of misinformed, and misconceived systems of knowledge/power apparatuses.

Prospectively, Said insisted that though the relationship between the Orient and the Occident has sometimes been conflictual, there have nevertheless been fruitful and significant encounters and exchanges between them in history. Said argued that a normative element in favor of interlocutory cultural and civilizational dialogue should be injected in both academia and practical politics, to bring about change and hope for humanity. Said's humanistic intellectual sphere has facilitated this dialogue between cultures, rendering the Occident-Orient dichotomy as a matter of cultural variations to be morally tolerated, or even culturally accepted rather than a mode of binary perspective and opposite reality.

\section{References:}

1. Alfonso, R. M. (2001). Other Worlds: Edward Said and Cultural Studies, Revista de Estudios Norteamericanos, 8, 49-59.

2. Al-Mahfedi, M.H.K. (2013). Edward Said's Concept of OccidentOrient Dichotomy: An Arab Perspective, Ph.D Thesis. Faculty of Humanities, University of Mysore.

3. Ashcroft, B. \& Ahluwalia, P. (2001). Edward Said. $2^{\text {nd }}$ ed. London: Routledge.

4. Bhattacharya, M. (2003). Edward W. Said: The Critic between the Text and the World, Social Scientist. 31. (9/10), 108-112.

5. Bove, P. A., ed. (2000). Edward Said and the Work of the Critic: Speaking Truth to Power. Durham: Duke UP.

6. Bove, P. A.(1993). Hope and Reconciliation: a Review of Edward W. Said, boundary 2, 20 (2), 266-282. 
7. Brennan, T. (2000). The Illusion of a Future: Orientalism as Traveling Theory, Critical Inquiry, 26 (3), 558-583.

8. Deer, P. et al. (2006). Edward Said: A Memorial Issue, Social Text, 87 (24), 1-10.

9. Frank, M. C. (2009). Imaginative Geography as a Travelling Concept, European Journal of English Studies, 13(1), 61-77.

10. Ghazoul, F. J. (2004). Orientalism: Clearing the Way for Cultural Dialogue. Religion, 34, 123-127.

11. Huntington,S. P. (1997). The Clash of Civilizationsand the Remaking of World Order. New York: Touchstone.

12. Linhard, T. (2011).In that Precarious Exilic Realm: Edward Said's Andalusian Journeys, Quaderns de la Mediterrània, 16, 169-182.

13. Parry, B. (1992). Overlapping Territories and Intertwined Histories: Edward Said's Postcolonial Cosmopolitanism. In M., Sprinker (Ed.).

14. Edward Said: A Critical Reader (pp.19-47).Cambridge: Blackwell.

15. Said, E. W. (1975). Beginnings: Intention und Method . New York: Basic Books.

16. Said, E. W. (1978). Orientalism ( $2^{\text {nd }}$ ed). London: Penguin Books.

17. Said, E. W. (1983). The World, the Text, and the Critic. Cambridge: Harvard UP.

18. Said, E. W. (1994). Culture and Imperialism. New York: Vintage. Print.

19. Said, E. W. (1994) Representations of the Intellectual: The 1993 Reith Lectures. New York: Vintage Books.

20. Said, E. W. (1995). An Ideology of Difference. In E. W, Said. (Ed.) The Politics of Dispossession ( $1^{\text {st }}$ ed. pp.78-100). London: Vintage.

21. Said, E. W. (1995). Projecting Jerusalem. Journal of Palestine Studies, 25(1) 5-14.

22. Said, E. W. (2001). Reflection on Exile. In E. W, Said. (Ed.) Reflections on Exile and Other Literary and Cultural Essays. (pp.173186) Cambridge: Harvard University Press.

23. Said, E. W. (2001). History, Literature and Geography. In E. W, Said. (Ed.) Reflections on Exile and Other Literary and Cultural Essays (pp.453-473). London: Penguin.

24. Said, E. W. (2002). Andalusia's Journey. Travel + Leisure.

25. Said, E. W. (2003). Art, Culture and Nationalism. In E. W, Said. (Ed.) The End of the Peace Process: Oslo and After 2000. ( pp.260-265). New York: Vintage.

26. Said, E. W. (2003). Culture and Resistance. London: Pluto Press.

27. Said, E. W. (2004). Humanism and Democratic Criticism. New York: Columbia University Pres. 
28. Said, E. W. Orientalism as a tool of colonialism. (Youtube 10 minute video). https://m.youtube.com/watch?v=yH2T6a_2gBo PAPER

29. Xie, Shaobo. 2009. The Southern Question' and Said's Geographical Critical Consciousness. In R. Ghosh. Ed. Edward Said and the Literary, Social, and Political World (pp. 77-90). New York: Routledge. 